\title{
Innovation of Dokter Kependudukan Online (dr. KePO) in Improving Local Governance System in Gresik District, East Java Province
}

\author{
Asrori $^{1}$, Hotnier Sipahutar ${ }^{2}$, Adi Suhendra ${ }^{3}$, Herman Yaarozatulo Harefa ${ }^{4}$, Yusniah \\ Anggraini $^{5}$ \\ \{asrori2011@yahoo.com ${ }^{1}$, hotniersipahutar@gmail.com², adisuhendra.pm@gmail.com ${ }^{3}$, \\ harefa1972@gmail.com ${ }^{4}$,yusnia.anggraini@gmail.com ${ }^{5}$ \}
}

Research and Development Agency, Ministry of Home Affairs, Indonesia ${ }^{12345}$

\begin{abstract}
The study is about the innovation of Dokter Kependudukan Online (Dr.KePO) in improving local governance in Gresik district, East Java province. This study was motivated by the existence of a new paradigm in local government services at the village level. The aims of this study were to improve the performance of local government administration. This study uses a qualitative method. Triangulation of data sources was to explore the truth of certain information through various methods and sources of data collection. Participant observation, written documents, archives, historical documents, official records, personal notes or writings and pictures to produce different evidence or data. While data processing, researchers performed data reduction. The reason for choosing this method because this study was a contemporary social event or phenomenon. With this method, researchers can make observations and in-depth interviews with careful subjects. The results obtained in this study were that the regional government of Gresik district has carried out several social interventions to improve services to the community from city to rural levels. Local government intervention in this context was Department Demography and Civil Registration which directs the creation of innovation in facilitating population administration management services and civil registration.
\end{abstract}

Keywords: Regional Government, Rural Innovation, Social Intervention, Technology Innovation, Policy Innovation

\section{Introduction}

The Indonesian government issued Government Regulation No. 38 Year 2017 concerning Regional Innovation. According to this regulation, Regional Innovation aims to improve the performance of regional governance. In order to achieve the objectives as intended, the target of Regional Innovation is directed at accelerating the realization of public welfare through improving Public Services, empowerment and community participation and enhancing Regional competitiveness. It is further explained in regional development, in that regulation the form of Regional Innovation includes innovation in Regional governance, Public Service innovation and other Regional Innovation in accordance with Government Affairs which is the authority of the Region (Government Regulation Number 38, 2017). 
In line with the above objectives, decentralization or regional autonomy has provided opportunities for local governments with their powers to try to strengthen public services that side with the public interest. With regional innovation, local government can make innovative innovations that are useful for the community, especially in making innovations in governance. In that context, this study seeks to describe the various efforts made by local governments in realizing public services and good local governance through regional innovation. This study seeks to find out how local government efforts to create regional innovations within the internal regions in local governance.

As has been done by the Regional Government of Gresik district in East Java Province. This area has a connection in building digital innovation in serving population and civil registration. This district makes an important investment in building a city. Investment in innovation is one of the important forces to accelerate regional development. To stimulate investment in innovation requires clear and comprehensive agendas that are internally created by local government. Directed innovation investment of public services ranging from the lower level to the level of implementing the regional organizations.

Based on previous research, there have been quite a lot of studies that have reviewed interventions by conducting digital innovations, especially research conducted by developed countries. For example Taalbi, this article examines an unresolved problem in innovation studies is the extent and how innovation is affected by changes in the economic environment. This study outlines a theoretical framework that unites theories of innovation as a creative response to complexity economy. In the empirical section, the results of a new micro-based database on Swedish product innovations, 1970-2007, were introduced. Applying the theoretical framework, both the quantitative evidence and innovation biographies gathered inform about the historical impulses that shaped innovation activity in the Swedish economy in two major waves during the 1970s and 1990s.

This study shows that, rather than as a result of ongoing efforts, most innovations were developed in response to discrete events, historical specific problems and new technological opportunities. It was also suggested that the creative response patterns were industry specific and related to the radicality and complexity of the innovation process [2]. Other research Suhendra, is about government reform carried out by city governments using innovation. This research was motivated by the efforts of the local governments of Tangerang Selatan and Magelang city in improving public services, governance and regulations. The purpose of this study was to explain innovation in governance and public services at the city level [3].

In line with Taalbi, Schwartz, Weiss, \& amp; Wiley [4] describes institutional interventions and innovative programs implemented to promote community and collaboration among faculty who teach virtually. Creating strategic opportunities for virtual and ground-based faculty to connect informally and formally has the potential to foster a culture of inclusiveness, connections, and a productive community of practice. The social work profession has utilized technology in such a way that the field has undergone many changes in the education and training of social workers as well as the ways in which services can be provided to clients. Meanwhile, Suryaweti et al. [5] identified problems and built a conceptual model related to local fiscal health conditions in a local government in Bondowoso district, East Java Province. The state of the fiscal health of the region is highly dependent on many factors, indicating that regional finance is a complex, systemic and unstructured process.

However, the above studies emphasize certain elements, namely around the economy and social innovation. In contrast to the research conducted above, this study seeks to examine digital innovation from several local government perspectives. This research is also 
considered important and relevant in seeing the contemporary context in Indonesia. The context of smart city development meant in the context of the state's obligation to provide public services for its citizens. In the consideration of Act Number 25-year 2009 concerning Public Services, it is also stated that the State is obliged to serve every citizen and resident to fulfill their basic rights and needs within the framework of public services as mandated by the Act year 1945, building public trust in public services carried out by public service providers is an activity which must be done in line with the hopes and demands of all citizens and residents about improving public services.

\section{Research Method}

This study uses in-depth interviews and field observations, the data analyzed by nonstatistical means [6] in accordance with the nature of the descriptive research method where researchers would make a systematic, factual, and accurate description of the facts of the problem in Gresik district and East Java Province. Researchers used a qualitative approach with descriptive research methods to describe village innovations. The qualitative approach is an approach that provides the opportunity for researchers to do an in-depth description of the subject, and get depth of information, as well as a wealth of interpretation [7].

In obtaining data sources, this study uses secondary data obtained from regional innovation index data. This data was collected into a database of results from reporting innovations from local governments to the Ministry of Home Affairs. While data processing, researchers performed data reduction. as explained [8] Data reduction This was intended to direct attention to the focus of research needs, simplify, and transform raw data into a form that was more manageable. Data reduction was carried out by researchers throughout the research process.

The existence of researchers at the Research and Development Agency of the Ministry of Home Affairs in observing innovation in local government makes researchers understand and hear directly the conversations and stories of the Regional Heads or Village Officials Organization, discuss with them, conduct interviews, read local media reports, and verify data and information from predecessors to existing stakeholders.

\section{Results and Discussion}

\subsection{Data Recording Problems of Population and Public Street Lighting}

Governance problems are a classic problem in the world of regional governance. Suppose the first problem is in the field of population. The realization of an orderly population administration based on the National Resident Identity Card through the Population Database is one of the targets and performance indicators that must be achieved in the 2015-2019 National Medium Term Development Plan (RPJMN). Strengthening infrastructure and superstructure of population administration services through the development of a Population Administration Information System, updating, improving the accuracy of registration data, the usefulness of population data, and strengthening public education in reporting population events were strategies that preferred in realizing the unified identity of the population.

In the constellation in Gresik district, employees at the Department of Population and Civil Registration found problems as a priority for acceleration in 2016, namely first, 
recorded 72,057 family cards or $19 \%$ of the 376,023 family cards in Gresik Regency are duplicate data and anomalies. It is recorded that 273,514 biodata are anomalies with a composition of $89.36 \%(244,424)$ are inactive anomalous biodata with an indication that the family does not have a family card or one of the family members does not have a Residence Identification Card does not change the data / does not have a birth certificate.

Second, the registration of birth certificates for Gresik district has reached $84.83 \%$ (has exceeded the national target of $77.5 \%$ ) but due to the dynamic development of the $0-18$ year age group and the not yet integrated birth registration before 2010 (due to the system switch from the Information System Population Management to Population Administration Information System) still leaves 172,511 people aged 0-18 years who do not have a birth certificate or have a certificate but are not yet integrated into the Population Administration Information System. Third, death reporting is getting better from 0 (2015) to 12,872 Deeds (2016). However, a total of 147,576 people $(15.2 \%$ of whom are required to have a Residence Identification Card) have not recorded.

On the other hand, there were actually fundamental problems that greatly affect population admin services. The first problem was that education and public awareness of population registration were hampered due to a regulation by the admin of the Directorate General of Population and Civil Registry which presents 117 forms for its services. Second, population mobility was very high considering that Gresikas as a suburb of the Surabaya Metropolitan Area, as recorded in 2015 that the dynamics of population change were influenced by mobility in / out of 51,291 people $(84.09 \%)$, followed by deaths of 7,979 people $(13.08 \%)$ while births of $1,725(2.83 \%)$ people. Third, In addition, the demographic conditions of Gresik with 356 villages (30 villages in the Bawean Islands) and insufficient literacy of technology in rural areas also obstruct our services.

Administrative service entities with their various problems as one of the basic needs of course affect all groups of society including the poor, illiterate, disabled, elderly, immigrants, women, youth, and various other groups. In addition, invalid registration of population data hinders the implementation of democratic development and public services, both basic and non-basic, such as holding general elections, distributing poverty alleviation assistance that is not on target, thus hampering the realization of a smart city.

\subsection{Innovation of Dokter Kependudukan Online (dr. KePO)}

This study looks at several local government interventions to change problems that exist at the local level. Social intervention is a method used in practice in the field to re-improve social welfare [9]. Social intervention is a planned change effort towards individuals, groups and communities [10]. It says "planned change" so that the assistance efforts provided can be evaluated and their success can be measured. Planned social change at the broader macro level (high level macro intervention), or often referred to as social change at the macro level. Here, changes are directed at efforts to change society more broadly, namely through social policies and legislation [11].

The main goal of Dr. KePO was to create a unified identity through simple and educational digital services supported inclusively by strengthening the role of Village Register officers, while the target groups were all levels of society as well as population administration service officers. 


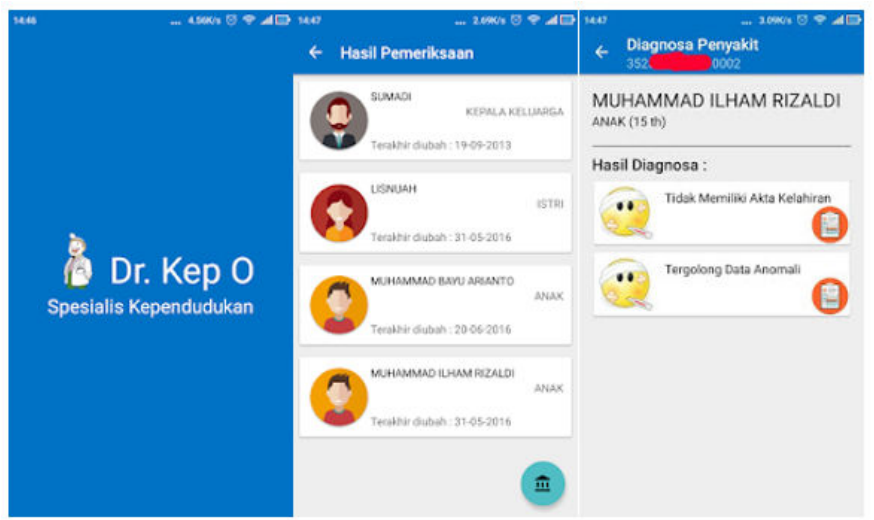

Fig 1. Dr. KePO Application

From the Population and Civil Registration Agency document, Dr. KePO's services have succeeded in providing a concrete impact in improving the quality of services for the admin of the Directorate General of Population and Civil Registry to the public. The various benefits referred to include the first. Dr. KePO's services improve education for the public to better understand population registration, especially information on the basic needs of his and all family members who have or have not been fulfilled, diagnosis of residential diseases of family members, and information on prescription for disease management or population administration service procedures and civil registration.

Strengthening public awareness through dr.KePO education is in line with increasing the frequency of services both in the recovery of multiple and anomalous data, population services and registration of civil registration certificates (birth, marriage and death). As explained from 72,057 Family Cards or 19\% of 376,023 Family Cards from Gresik district were duplicate data and anomalies, as many as 14,393 households have been updated (20\%). There is an increase in anomaly and multiple data updating services when viewed from the monthly progress even though the anomaly and double data were dynamic.

As for 273,514 anomalous biodata, as many as 68,204 (25\%) biodata have been recovered. The registration of birth certificates in Gresik district has reached $84.83 \%$ (has exceeded the national target of 77.5\%) with ownership of 195,684 deeds (deeds that are registered and have been integrated with the Population Information and Administration System). The recording data for death certificates reached 12,873, while the data that had not been recorded from 147,576 people ( $15.2 \%$ of the mandatory ID cards) decreased to 96,939 $(9.86 \%)$ of the total required to record.

Second, dr. Kepo has improved the quality, speed, and accuracy of the civil service administration by presenting an easy and simple service. Dr. KePO's services have transformed 117 admin service forms of the Directorate General Population and Civil Registry into digital form. Each required form will automatically appear and complete so there is no need to search, compile, or memorize the required form (paperless and timesaving). In addition, it was sufficient to enter the Family Card Number on the first page, it would automatically fill in the identity of the required population in a digital form so that residents can simply fill in other indicative data needs. This simplicity and simplicity make it 
easier for the community to take care of administrative services both in filling out service forms and obtaining information related to required documents. In addition, Dr. KePO's services could be accessed via smartphones, making it easier for the community to use them, especially workers with high mobility.

In addition to the community, service personnel were also facilitated because the service that was originally manual has switched to digital, no longer requires a lot of paper, saves time, and no longer needs to search or compile service files and memorize 117 administrative service forms. The dr.KePO application provides inclusive services supported by strengthening the role of Village Register Officers with networks in each village involving neighborhoods / hamlets, family planning counselors, village midwives, and other stakeholders such as Karangtaruna, Family Welfare Movement so that not only registrars but development actors others could facilitate the community, especially those with low technological literacy. Strengthening networks is evidenced by easier and faster channels of instruction, information sharing, and consultation through the formation of WhatsApp groups at the agency, sub-district, and village levels.

\subsection{Diffusion of Regional Innovation}

The Innovation Diffusion Theory basically describes the process by which an innovation is conveyed (communicated) through certain channels all the time to a group of members of the social system. This is in line with the definition of diffusion from Rogers [12], namely "as the process by which an innovation is communicated through certain channels over time among the members of a social system." It is further explained that diffusion is a form of communication that is specifically related to the dissemination of messages in the form of new ideas. Furthermore, Rogers and Shoemaker explained that the diffusion process is part of the process of social change.

Social change is a process by which changes occur in the structure and function of social systems [13]. Social change occurs in 3 (three) stages, namely: (1) invention, (2) diffusion, and (3) consequences. Discovery is the process by which new ideas are created or developed. Diffusion is the process by which new ideas are communicated to members of the social system, while the consequence is a change in the social system as a result of the adoption or rejection of innovation.

Basically, the community also needs a set of tools to support various kinds of production activities, either related to rubber production or its economic needs. For this reason, institutions are something that is really needed in order to fulfill this production. According to North, institutions or institutions are the rules (constraints) created by humans to regulate and shape political, social and economic interactions. This institution was highly influenced by the prevailing norms and values and the complexity of the economy so that the needs and forms of the institutions would differ from one country to another depending on the bureaucratic culture they have. In practice, the social actions of the community become a social rational act that creates friendly relations between the bureaucracy and society.

If you see the results, Dr. Kepo produced many things. First, the concrete output that shows success in the service of Dr. KePO, for example first, from 72,057 family cards or $19 \%$ of the 376,023 family cards in Gresik district were duplicated data and anomalies, as many as 14,393 households have been updated (20\%). There is an increase in anomaly and multiple data updating services when viewed from the monthly progress even though the 
anomaly and double data are dynamic. Second, the registration of birth certificates in Gresik district has reached $84.83 \%$ (has exceeded the national target of $77.5 \%$ ) with ownership of 195,684 deeds (registered deeds that have been integrated with Population administration and information system);

Third, the improvement in the performance of Village registers officers who previously required 30-45 minutes to fill in service forms manually has now been shortened to 3-5 minutes per service. Fourth, increasing the usefulness of population data. The family card number entry system to bring up family members is used by other agencies as an example; The Social Service uses dr. KePO to verify the status of identity of prospective beneficiaries of the Gresik Health Card and Healthy Indonesia Card assistance, the Office of Family Planning, Women's Empowerment and Child Protection makes use of it in realizing protection of children's legal identities (children's forums);

The Agency for Regional Development plans to use Dr. KePO's tools to verify the list of beneficiaries and social assistance for and support in the preparation of the Gresik Inclusive Decision Support System (GIDSS); Fifth, increasing the accessibility of administrative services to remote villages, supported by networks via WhatsApp Group and computer and network devices that are available in all villages. Among them are providing convenience for admin services of the Directorate General of Population and Civil Registry, especially for residents with high mobility through the use of the android version of the Dr. KePO application.

\section{Conclusions}

The regional government of Gresik district has carried out several social interventions to improve services to the community from city to rural levels. Local government intervention in this context was the Directorate General Population and Civil Registry to direct the creation of innovations in facilitating population administration management services and civil registration. Planned change efforts for individuals, groups, and communities include change using innovative policies and support from technological innovation. The creation of innovations in technology and information application platforms is a policy innovation and service programs have been carried out by the government. However, even if an innovation policy has been well designed, it does not mean that its implementation will be in accordance with the expected objectives. The success of a policy can be seen from how the policy could be transformed into a more applicable guideline to guide policy implementation in a city.

\section{Acknowledgement}

The researcher would like to thanks the Head of the Research and Development Center for Regional Innovation of the Ministry of Home Affairs, the Regent of Gresik, the Head of the Regional Planning and Development Agency for Gresik District and Herie Saksono, Imam Radianto as Researchers of the Research and Development Agency of the Ministry of Home Affairs who has provided many suggestions for this study. 


\section{References}

[1] Peraturan Pemerintah Nomor 38 Tahun 2017 Tentang Inovasi Daerah. Jakarta: Sekretariat Negara, 2017.

[2] J. Taalbi, "What drives innovation? Evidence from economic history," Res. Policy, vol. 46, no. 8, pp. 1437-1453, 2017.

[3] A. Suhendra, "Inovasi Daerah dalam Reformasi Pemerintahan Kota Tangerang Selatan dan Kota Magelang," Matra Pembaruan, vol. 2, no. 1, pp. 39-48, 2018.

[4] S. L. Schwartz, E. L. Weiss, and J. L. Wiley, "Innovative Strategies for Building Community Among Faculty Who Teach in Virtual Environments," Adv. Soc. Work, vol. 18, no. 4, pp. 1103-1112, Jan. 2019.

[5] D. Suryawati et al., "Fiscal Health in Local Government Based on Soft System," vol. 11, no. 2, pp. 224-243, 2018

[6] A. Bryman, Social Research Methods, Fourth Edi. New York: Oxford University Press, 2012.

[7] E. Rubin, Allen; Babbie, Research Methods for Social Work. Belmont: Linda Schreiber, 2011.

[8] A. Strauss and J. Corbin, "Grounded Theory Methodology," in Handbook of Qualitative Research, 2nd Ed., 1994, pp. 273-285.

[9] C. Zastrow, Introduction to Social Work and Social Welfare Empowering People, Twelfth. Boston: Cengage Learning, 2017.

[10] I. R. Adi, lmu Kesejahteraan Sosial dan Pekerjaan Sosial: Pengantar Pada Pengertian dan Beberapa Pokok Bahasan. Jakarta: FISIP UI Press, 2005.

[11] M. Payne, Modern Social Work Theory, 4th ed. New York: Palgrave Macmillan, 2014.

[12] E. M. Rogers, Diffusion of Innovations. 1995.

[13] M. Dziallas and K. Blind, "Innovation indicators throughout the innovation process: An extensive literature analysis," Technovation, vol. 80pp. 3-29, 2019. 